\title{
DIGLOSIA
}

Volume 2, Nomor 1 (Februari 2019)

p-ISSN 2615-725X (Print)

Halaman 15-38

e-ISSN 2615-8655 (Online)

\section{STRATEGI KOMUNIKASI SISWA DAN GURU KELAS XI SMAN 2 SANGATTA UTARA DALAM PROSES PEMBELAJARAN BAHASA INDONESIA}

\author{
Syawal Arifin ${ }^{1, *}$, Masrur Yahya ${ }^{2}$, Mohammad Siddik ${ }^{3}$ \\ ${ }^{1}$ Magister Pendidikan Bahasa dan Sastra Indonesia, FKIP, Universitas Mulawarman \\ ${ }^{2,3}$ Fakultas Keguruan dan Ilmu Pendidikan Universitas Mulawarman \\ 1,* Pos-el korespondensi: arifinsyawal12@gmail.com
}

\begin{abstract}
The mastery of various foreign languages causes frequent obstacles in the delivery of messages to the speech partners. As a result, teachers and class XI students of SMAN 2 Sangatta Utara used various communication strategies to deal with these obstacles. This study aims to describe the communication strategies used by teachers and class XI students of SMAN 2 Sangatta Utara in the class of Indonesian Language lessons. This research was done by a descriptive method and qualitative approach. The data was collected in March to October 2017 from one classroom teacher and one class XI of grade student of SMAN 2 Sangatta Utara. Data retrieval was carried out during the teaching and learning activities in the classroom when the teacher is teaching the Indonesian language. This study uses skillful free listening techniques to collect data. The data analysis was used the flow technique, namely (1) data reduction, (2) data presentation, and (3) drawing conclusions. The validity test of the data is done by (1) persistence observations, (2) peer examination, and (3) triangulation. The results study included: (1) when communicating with classmates, students use various communication strategies namely imitation communication strategies, the use of certain body language according to the meaning of communication that they want to achieve, and the transfer awareness communication strategies. (2) communication strategies in the classroom are mostly carried out by the teacher when communicating with students. The communication strategy of students with teachers includes (a) paraphrase, (b) transfer awareness type, (c) asking for help type, (d) avoiding type and (e) imitating type.
\end{abstract}

Keywords: communication strategies, student and teacher, learning process

\begin{abstract}
ABSTRAK
Penguasaan bahasa yang bermacam-macam menyebabkan sering terjadi beberapa kendala dalam penyampaian pesan kepada mitra tuturnya. Akibatnya, guru dan siswa kelas XI SMAN 2 Sangatta Utara menggunakan berbagai strategi komunikasi untuk menghadapi kendala tersebut. Penelitian ini bertujuan untuk menghasilkan deskripsi tentang strategi komunikasi yang digunakan guru dan siswa kelas XI SMAN 2 Sangatta Utara ketika proses pembelajaran bahasa Indonesia di kelas. Metode yang digunakan pada penelitian ini adalah metode deskriptif dan pendekatan kualitatif. Sumber data penelitian ini sebanyak satu orang guru kelas dan siswa kelas XI SMAN 2 Sangatta Utara. Pengambilan data dilakukan pada saat berlangsungnya KBM di kelas ketika guru sedang mengajar bahasa Indonesia dan dilakukan mulai Maret 2017 s.d. Oktober 2017. Penelitian ini menggunakan teknik simak bebas libat cakap untuk mengumpulkan data. Teknik analisis data yang digunakan adalah dengan teknik alir, yaitu: (1) reduksi data, (2) penyajian data, dan (3) penarikan simpulan/verifikasi. Uji keabsahan data dilakukan dengan (1) ketekunan pengamatan, (2) pemeriksaan teman sejawat, dan (3) triangulasi. Hasil penelitian berupa strategi: (1) Saat berkomunikasi dengan teman
\end{abstract}


sekelas, siswa menggunakan berbagai strategi komunikasi, berupa strategi komunikasi peniruan, penggunaan bahasa tubuh tertentu sesuai dengan makna komunikasi yang ingin dicapainya, dan strategi komunikasi tipe kesadaran transfer. (2) Strategi komunikasi di kelas kebanyakan dilakukan oleh guru saat berkomunikasi dengan siswanya. Strategi komunikasi siswa dengan guru berupa: (a) strategi parafrase, (b) tipe kesadaran transfer, (c) tipe meminta bantuan, (d) tipe menghindar, dan (e) tipe peniruan.

Kata Kunci: strategi komunikasi, siswa dan guru, proses pembelajaran

\section{A. PENDAHULUAN}

Bahasa menduduki posisi atau fungsi yang sangat penting dalam kehidupan manusia, salah satu fungsi bahasa adalah sebagai alat komunikasi. Manusia dalam kehidupan, tidak pernah lepas dari penggunaan bahasa untuk memenuhi keperluan hidupnya. Bahasa mempunyai sistem yang mempertautkan seperangkat kata atau ungkapan yang digunakan untuk menyebut dan memanggil nama para pelaku dalam suatu peristiwa bahasa (Kridalaksana, 1980:14). Penggunaan bahasa dapat secara tertulis dan lisan. Penggunaan bahasa secara tertulis dilakukan dengan menggunakan media tertentu. Misalnya, melalui karangan, melalui media sosial (SMS, twitter, whatsapp, line, facebook, dll). Penggunaan bahasa secara lisan lazim disebut berbicara. Berbicara dengan orang lain merupakan salah satu wujud berkomunikasi.

Siswa mengalami beberapa kendala ketika berkomunikasi, seperti; kendala dalam pesan kepada lawan tuturnya, bagaimana cara mengekspresikan diri, memilih kata yang tepat, mengucapkan kata dengan benar, dll. Untuk mengatasi beberapa kendala tersebut, diperlukan strategi komunikasi. Strategi komunikasi adalah teknik sistematis yang diterapkan penutur untuk mengekspresikan makna saat menghadapi beberapa kesulitan dalam komunikasinya (Corder, 1977:34). Ketika mengalami kendala pada saat berkomunikasi, seorang penutur akan menggunakan cara-cara tertentu yang berkesinambungan. Cara-cara yang dapat digunakan misalnya dengan strategi komunikasi penghindaran, strategi komunikasi pengganti, dan strategi komunikasi meminta bantuan. Harapannya, setelah menggunakan satu atau beberapa strategi komunikasi, kendala-kendala yang dihadapi dapat diselesaikan dengan baik sehingga pesan atau informasi yang ingin disampaikan oleh penutur dapat tersampaikan dengan baik kepada petuturnya.

Strategi komunikasi yang digunakan oleh seorang penutur terutama para siswa Sekolah Menengah Atas (SMA) dalam memahami pesan yang ingin disampaikan, sangat menarik untuk dibicarakan. Hal ini disebabkan dalam proses perkembangan bahasanya, seorang siswa tidak saja berusaha memproduksi kalimat-kalimat, tetapi lebih pada usaha siswa tersebut untuk mengomunikasikan makna yang disebabkan siswa tersebut kekurangan persyaratan pengetahuan linguistik. Persyaratan pengetahuan linguistik yang dimaksud adalah segala sesuatu yang berkaitan dengan linguistik, misalnya; kosakata, frase, atau kalimat tertentu sesuai dengan makna yang diinginkan oleh penutur pada saat mereka berkomunikasi.

Adanya kekurangan persyaratan pengetahuan linguistik pada penutur berkaitan dengan proses pemerolehan bahasa yang terjadi pada diri mereka. Apabila proses pemerolehan bahasa yang terjadi pada diri penutur siswa berjalan dengan baik, harapannya tidak ada kendala-kendala dalam memahami pesan yang ingin disampaikan ketika berkomunikasi. Perbedaan-perbedaan yang dimiliki oleh individu pembelajar 
merupakan salah satu faktor yang menyebabkan adanya kendala-kendala pada saat pemerolehan bahasa berlangsung. Terdapat dua proses yang terjadi ketika seseorang memperoleh bahasa, yaitu: proses pemahaman dan proses penggunaan. Kedua proses tersebut saling berkait dan saling memengaruhi. Apabila kedua proses tersebut telah dikuasai oleh seseorang dalam memperoleh bahasa, orang tersebut sudah memperoleh bahasa dengan baik.

Proses pemahaman merupakan proses penguasaan tata bahasa yang berlangsung secara tidak disadari. Proses penggunaan adalah proses untuk menampilkan kemampuan kompetensi yang telah dimiliki oleh seseorang pada saat ia memperoleh bahasa. Dalam bidang pemerolehan B2, proses performansi dikenal dengan strategi komunikasi (Pringgowidagdo, 2002:120). Pada dasarnya, strategi komunikasi lebih mengacu pada output bagaimana penutur mengekspresikan makna bahasa yang telah diperoleh atau dipelajarinya. Output tersebut misalnya pemilihan kata atau gerak tubuh tertentu yang mendukung penyampaian pesan agar dapat diterima dengan baik oleh mitra tuturnya. Untuk dapat mengekspresikan makna bahasa dengan baik, diperlukan upaya-upaya tertentu dari penutur agar makna atau informasi yang ingin disampaikan kepada mitra tuturnya dapat dipahami dengan baik.

Strategi komunikasi mempunyai beberapa wujud yang telah dikemukakan oleh beberapa ahli. Wujud strategi komunikasi adalah pengelompokan berdasarkan jenis-jenis utama strategi komunikasi (Tarone dalam Bialystok, 1990:39). Tarone berusaha membuat klasifikasi strategi komunikasi berdasarkan berbagai macam tuturan yang terjadi dalam kehidupan masyarakat. Klasifikasi strategi komunikasi tersebut merupakan beberapa wujud strategi komunikasi yang terdiri atas: (1) tipe menghindar, (2) tipe parafrase, (3) tipe kesadaran transfer, (4) tipe permintaan bantuan, dan (5) tipe peniruan (Tarone dalam Bialystok, 1990:39).

Tuturan siswa pada hubungan kata dan kehadiran aturan kebahasaan yang digunakan bergantung kepada beberapa faktor. Beberapa faktor tersebut antara lain: (1) dengan bahasa apa seorang siswa bertutur, (2) kepada siapa siswa tersebut menyampaikan tuturannya, (3) dalam situasi bagaimana tuturan itu disampaikan, dan (4) kemungkinan-kemungkinan struktur manakah yang ada dalam bahasa yang dipergunakannya (Suwito, 1983:31). Artinya, aturan kebahasaan pada tuturan siswa berkaitan dengan beberapa faktor penentu yang menyebabkan tuturan siswa tersebut berbeda dengan tuturan orang dewasa. Beberapa faktor yang dimaksud yaitu; (1) setiap siswa memiliki ciri kebahasaan tersendiri yang berbeda antara siswa yang satu dengan yang lainnya, (2) siapa yang menjadi kawan tuturnya, (3) situasi dan kondisi, serta (4) kemungkinan strategi komunikasi yang digunakan. Dengan demikian, siswa memiliki aturan tersendiri dan menggunakan strategi tertentu ketika berkomunikasi. Antara siswa yang satu dengan siswa yang lain mempunyai aturan-aturan kebahasaan dan strategi komunikasi sendiri (bersifat individual). Keadaan tersebut sangat menarik untuk dicermati menjadi suatu penelitian dan menjadi alasan kedua dilaksanakannya penelitian ini.

Siswa yang satu dengan yang lain pada saat berada di kelas seringkali diperlakukan sama oleh guru ketika mereka berkomunikasi. Banyak guru belum memahami bahwa setiap siswa mempunyai aturan-aturan kebahasaan dan strategi komunikasi sendiri (bersifat individual). Adanya strategi komunikasi yang bersifat individual seharusnya direspon dengan strategi komunikasi yang bersifat individual juga dari seorang guru. Harapannya, jika guru dapat memberikan respon strategi komunikasi yang bersifat 
individual kepada siswa, perkembangan kemampuan berbahasa siswa akan dapat berkembang dengan baik yang berpengaruh pada perkembangan kognisi siswa sehingga berdampak pula pada perkembangan kecerdasan siswa. Keadaan tersebut yang menjadi alasan ketiga dilakukannya penelitian ini.

Penelitian ini mengambil subjek penelitian siswa yang berusia 15-17 tahun dan berada di kelas XI Sekolah Menengah Atas (SMA). Hal ini dilakukan dengan pertimbangan bahwa siswa usia 15 sampai 17 tahun memperlihatkan sifat yang berbeda dengan sifat orang dewasa. Siswa pada usia ini mempelajari bahasa dengan semangat yang tinggi. Mereka bisa dengan cepat menirukan bunyi-bunyi bahasa serta tidak terpengaruh oleh kesalahankesalahan yang dibuat di muka umum (Rombepajung, 1988:7). Bahkan, menurut Mar'at (2005:67) masa anak merupakan masa berkembangnya kognisi sehingga perkembangan bahasa juga berkembang yang tercermin pada kemampuan anak dalam bidang linguistik.

Siswa kelas XI SMAN 2 Sangatta Utara dijadikan sebagai lokasi penelitian karena peneliti melihat siswa kelas XI di SMA tersebut menggunakan bermacammacam B1. Bahasa pertama yang digunakan, antara lain: bahasa Kutai, bahasa Kutai dicampur bahasa Indonesia dialek Kutai, Bahasa Indonesia dicampur bahasa Toraja, Bugis, dan Jawa, serta bahasa Indonesia. Penggunaan B1 yang bermacam-macam menyebabkan sering terjadi beberapa kendala dalam penyampaian pesan kepada lawan tuturnya. Akibatnya, siswa kelas XI di SMAN 2 Sangatta Utara menggunakan strategi komunikasi untuk menghadapi beberapa kendala tersebut. Berdasarkan uraian tersebut di atas, maka penelitian ini bertujuan untuk menghasilkan deskripsi tentang strategi komunikasi yang digunakan guru dan Siswa kelas XI SMAN 2 Sangatta Utara ketika proses pembelajaran bahasa Indonesia di kelas.

\section{B. LANDASAN TEORI}

\section{Pembelajaran Bahasa Indonesia Kelas XI SMA}

Tujuan Pembelajaran Bahasa Indonesia Kurikulum 2013, mata pelajaran Bahasa Indonesia bertujuan agar peserta didik memiliki kemampuan sebagai berikut; (1) Memahami struktur teks, baik dalam genre sastra maupun nonsastra, dan unsur kebahasaan serta fungsi sosialnya, (2) Membandingkan teks dalam bentuk lisan dan tulisan dan menganalisis teks baik melalui lisan maupun tulisan, (3) Mengevaluasi teks berdasarkan kaidahkaidah teks, baik melalui lisan maupun tulisan, (4) Menginterpretasi makna teks, baik secara lisan maupun tulisan, (5) Memproduksi teks, baik secara lisan maupun tulisan, (6) Menyunting teks sesuai dengan struktur dan kaidah teks, baik secara lisan maupun tulisan, (7) Mengabstraksi teks, baik secara lisan maupun tulisan, (8) Mengonversi teks ke dalam bentuk yang lain sesuai dengan struktur dan kaidah teks, baik secara lisan maupun tulisan (Kurikulum 2013).

Agar tujuan-tujuan tersebut dapat terlaksana dengan baik, perlu dirumuskan standar kompetensi mata pelajaran bahasa Indonesia. Standar kompetensi mata pelajaran Bahasa Indonesia merupakan kualifikasi kemampuan minimal peserta didik yang menggambarkan penguasaan pengetahuan, keterampilan berbahasa, dan sikap positif terhadap bahasa dan sastra Indonesia. Standar kompetensi ini merupakan dasar bagi peserta didik untuk memahami dan merespons situasi lokal, regional, nasional, dan global. Dengan standar kompetensi mata pelajaran Bahasa Indonesia ini diharapkan: (1) peserta didik dapat mengembangkan potensinya sesuai dengan kemampuan, kebutuhan, dan minatnya, serta dapat menumbuhkan penghargaan terhadap hasil karya kesastraan dan hasil intelektual bangsa sendiri, (2) guru dapat memusatkan perhatian kepada pengembangan 
kompetensi bahasa peserta didik dengan menyediakan berbagai kegiatan berbahasa dan sumber belajar, (3) guru lebih mandiri dan leluasa dalam menentukan bahan ajar kebahasaan dan kesastraan sesuai dengan kondisi lingkungan sekolah dan kemampuan peserta didiknya, (4) orang tua dan masyarakat dapat secara aktif terlibat dalam pelaksanaan program kebahasaan dan kesastraan di sekolah, (5) sekolah dapat menyusun program pendidikan tentang kebahasaan dan kesastraan sesuai dengan keadaan peserta didik dan sumber belajar yang tersedia, (6) daerah dapat menentukan bahan dan sumber belajar kebahasaan dan kesastraan sesuai dengan kondisi dan kekhasan daerah dengan tetap memperhatikan kepentingan nasional.

Ruang lingkup mata pelajaran Bahasa Indonesia mencakup komponen kemampuan berbahasa dan kemampuan bersastra yang meliputi aspek-aspek mendengarkan, berbicara, membaca, dan menulis (Kurikulum 2006/KTSP). Di dalam mata pelajaran bahasa Indonesia, terdapat pengetahuan dan keterampilan yang berkaitan dengan berbahasa. Pengetahuan dan keterampilan tersebut diberikan ketika siswa belajar bahasa Indonesia. Dengan menguasai pengetahuan dan keterampilan tersebut, siswa akan memiliki pengetahuan dan keterampilan berbahasa yang lengkap.

\section{Komunikasi}

Fungsi fundamental bahasa adalah sebagai alat komunikasi (Clark dan Clark, 1977:25). Penutur tidak dapat menyampaikan pesan atau informasi dengan baik apabila tidak menggunakan bahasa. Ketika berkomunikasi, terdapat tiga unsur utama, yaitu: penutur, petutur, dan sistem tanda. Penutur merupakan orang atau sekelompok orang yang menyampaikan pesan atau informasi kepada lawan tuturnya. Penutur disebut juga informan atau narasumber. Petutur adalah orang atau sekelompok orang yang menerima pesan atau informasi dari lawan tuturnya. Petutur disebut juga pendengar atau audience. Sistem tanda disebut juga bahasa. Bahasa yang digunakan ketika berkomunikasi harus dipahami dengan baik oleh penutur dan petutur. Jika tidak, terjadi gangguan berkomunikasi.

Kualitas pesan sangat penting dipertimbangkan ketika seseorang yang akan berkomunikasi (Hasling, 1998:14). Komunikasi dapat berlangsung dengan baik berdasarkan kualitas pesan yang disampaikan. Kualitas pesan meliputi isi dan struktur. Isi adalah proses untuk lebih mengembangkan isi pembicaraan dengan menyampaikan pesan yang mudah dipahami bagi penerima pesan. Struktur adalah urutan dan perkembangan pola bentuk-bentuk pemikiran dan ide-ide yang bernalar mulai dari awal s.d. akhir ketika berkomunikasi.

Untuk komunikasi dua arah, umpan balik sangat penting. Umpan balik digunakan untuk mengoreksi kesalahan atau kejelasan pesan bagi petutur (Hasling, 1998:9). Dengan adanya umpan balik, pesan yang disampaikan dapat dikoreksi oleh petutur apabila terjadi kesalahan atau ketidakjelasan. Umpan balik dapat berupa umpan balik verbal dan umpan balik nonverbal. Umpan balik verbal berupa tuturan yang dikemukakan oleh petutur untuk menanggapi tuturan penutur. Umpan balik nonverbal merupakan tuturan bukan lisan yang disampaikan oleh petutur dengan menggunakan alat bantu visual (grafik, denah, peta) atau gerakan tubuh tertentu (mengangguk atau menggelengkan kepala, tepukan tangan, dll.).

Jenis-jenis komunikasi meliputi komunikasi verbal, nonverbal, dan simultan. Komunikasi verbal merupakan penyampaian pesan yang diwujudkan dalam bentuk lisan/tertulis (DeVito, 1997:27-28). Adanya komunikasi secara verbal dapat diketahui dari tuturan atau tulisan seseorang. Tuturan yang disampaikan oleh penutur dapat 
berlangsung searah atau timbal balik. Tuturan searah misalnya seseorang berpidato, berorasi, berceramah, dll. Tuturan timbal balik dilakukan ketika berkomunikasi dengan orang lain. Tulisan seseorang misalnya short massage service (sms), facebook, twitter, whatsapp, karangan ilmiah, dll. Komunikasi verbal sangat mendominasi dalam kehidupan sehari-hari yang diwujudkan dalam bentuk kata-kata baik lisan/tulisan. Meskipun demikian, ada banyak hal yang tidak dapat dikomunikasikan dengan kata-kata (Hasling, 1998:181). Penutur kesulitan untuk memilih dan menggunakan katakata tertentu yang dapat mewakili ketuntasan pesan yang ingin disampaikannya. Apalagi, penutur yang masih anak-anak. Untuk mengatasi kesulitan tersebut, penutur bisa menggunakan alat bantu visual atau gerakan tubuh tertentu. Alat bantu visual misalnya grafik, gambar, denah, dll. Gerakan tubuh tertentu misalnya sentuhan, suara keras, kedekatan fisik, cara berjalan, berjabat tangan. Keadaan tersebut dinamakan komunikasi nonverbal (DeVito, 1997:27-28).

Kompetensi komunikasi adalah kemampuan penutur menghasilkan kalimat gramatikal suatu bahasa yang terinstitusionalisasi ketika melakukannya (Hymes, 1972:282). Kompetensi komunikasi berkaitan dengan kemampuan penutur menguasai suatu bahasa dan menggunakan sesuai dengan situasi dan kondisi ketika berkomunikasi. Kompetensi komunikasi melibatkan pengetahuan kaidah suatu bahasa, apa yang dikatakan, kepada siapa, dan bagaimana mengatakan secara benar dalam situasi tertentu. Dengan demikian, kompetensi komunikasi berkaitan dengan kemampuan penutur untuk berkomunikasi secara efektif.

Lebih lanjut, Hymes (1972:283) menyatakan kompetensi komunikasi adalah bagaimana seorang siswa menyadari dan mengategorikan situasi sosial dalam dunianya dan membedakan berbagai cara dalam suatu pertuturan. Kompetensi komunikasi yang dimiliki oleh seorang siswa berkaitan dengan kesadaran siswa tersebut sedang berada dalam situasi tertentu dan dapat menggunakan tuturan sesuai dengan situasi tersebut meskipun dengan caranya sendiri. Siswa belum memiliki pengetahuan kebahasaan yang sempurna, belum memahami sepenuhnya pesan yang disampaikan, dan belum mempunyai peran yang penting dalam suatu komunitas sehingga siswa mempunyai cara tersendiri ketika berkomunikasi. Kompetensi komunikasi pada siswa bukan dilihat dari besar atau kecil beberapa faktor penghambat dalam diri siswa tersebut tetapi dari kemampuannya berani berkomunikasi.

Strategi komunikasi adalah teknik sistematis yang diterapkan penutur untuk mengekspresikan makna/maksud saat menghadapi beberapa kesulitan dalam komunikasinya (Corder, 1977:34). Strategi komunikasi memerlukan cara-cara yang dilaksanakan penutur dengan baik. Caracara tersebut digunakan agar informasi/pesan yang ingin disampaikan oleh penutur kepada petuturnya dapat diterima dengan baik oleh petuturnya. Dengan demikian, strategi komunikasi memerlukan rangkaian perencanaan dan kesiapan dari penuturnya agar dapat berkomunikasi dengan baik.

Tarone (dalam Bialystok, 1990:6) menjelaskan strategi komunikasi dari segi konteks interaksi antarpembicara. Menurutnya, strategi komunikasi adalah upaya timbal balik dari interlokutor untuk mencapai kesepakatan dalam suatu maksud dalam situasi struktur makna yang diperlukan tidak dikemukakan. Menurut Tarone, strategi komunikasi merupakan kegiatan bersama dan timbal balik antara penutur dengan petuturnya. Ketika mengalami kendala, mereka membuat kesepakatan bersama untuk menggunakan cara apa dan bagaimana sehingga kendala 
tersebut dapat diatasi dengan baik. Dengan demikian, menurut Tarone, strategi komunikasi merupakan usaha penutur untuk mengatasi kendala pada saat berkomunikasi dengan persetujuan dari petuturnya.

Tujuan strategi komunikasi merupakan maksud yang ingin dicapai ketika berkomunikasi, meliputi: (1) memberitahu, (2) memotivasi, (3) mendidik, (4) menyebarkan informasi, dan (5) mendukung pembuatan keputusan (Liliweri, 2011:248). Selanjutnya Liliweri menyatakan bahwa kapasitas dan kualitas informasi yang akan disampaikan harus berkaitan dengan informasi utama atau informasi penting yang ingin disampaikan. Sebagai contoh, jika sebuah perusahaan ingin menerima calon pegawai baru, perusahaan tersebut akan memasang iklan di surat kabar. Terdapat banyak hal yang berkaitan dengan kriteria penerimaan pegawai, misalnya; kriteria pendidikan, umur, alamat, dan syarat-syarat lainnya. Namun yang dimaksud dengan informasi inti adalah kapan pendaftaran pegawai baru akan dibuka dan kapan pendaftaran tersebut akan ditutup. Berdasarkan contoh tersebut, dapat diketahui bahwa dalam penyampaian sebuah pemberitahuan, penutur harus dapat mengetahui mana informasi yang dianggap paling penting sehingga petutur dapat menerima dengan baik semua pesan atau informasi yang disampaikan oleh penutur.

Karakteristik strategi komunikasi meliputi: (1) problematika, (2) kesadaran, dan (3) intensionalitas (Bialystok, 1990:5). Problematika adalah karakteristik mendasar dan lazim untuk menggunakan strategi komunikasi tertentu. Strategi komunikasi tertentu digunakan hanya pada saat penutur menghadapi problem (kendala/masalah) dalam berkomunikasi. Adakalanya strategi komunikasi digunakan penutur meskipun tidak ada masalah dalam berkomunikasi. Dengan demikian, penggunaan strategi komunikasi yang utama untuk mengatasi kendala ketika berkomunikasi. Ketika berkomunikasi, penutur menyadari ada kendala untuk menyampaikan pesan kepada mitra tuturnya. Dengan kesadarannya pula, penutur ingin agar kendala tersebut dapat diatasi. Akibatnya, penutur menggunakan strategi komunikasi tertentu.

Pemilihan strategi komunikasi tertentu oleh penutur sesuai dengan situasi dan kondisi ketika berkomunikasi. Pemilihan strategi yang sesuai dengan situasi dan kondisi yang dilakukan oleh penutur disebut intensionalitas. Dengan demikian, intensionalitas merupakan penggunaan tipe strategi tertentu berdasarkan situasi dan kondisi yang terjadi ketika berkomunikasi. Penggunaan strategi komunikasi ditentukan oleh tipe tugas atau latihan, tipe masalah, dan tipe masalah yang dapat diangkat dalam komunikasi (Bialystok, 1990:8). Strategi komunikasi digunakan oleh penuturnya karena beberapa faktor penyebab. Faktor penyebab yang pertama, strategi komunikasi digunakan karena adanya tuturan dari mitra tutur yang tidak dimengerti oleh penutur. Karena adanya kendala ketika berkomunikasi, strategi komunikasi digunakan. Faktor tersebut merupakan faktor penyebab kedua. Faktor ketiga, yaitu: bentuk-bentuk kendala yang bermacam-macam menyebabkan strategi komunikasi digunakan. Faktor-faktor penyebab tersebut menentukan tipe strategi komunikasi tertentu digunakan oleh penuturnya.

Klasifikasi strategi komunikasi dikemukakan oleh beberapa ahli antara lain oleh Faerch dan Kasper. Faerch dan Kasper (dalam Bialystok, 1990:31) membuat klasifikasi strategi komunikasi berdasarkan pendapat Corder. Menurut mereka, penutur mempunyai dua pilihan ketika menghadapi kendala berkomunikasi. Kedua pilihan tersebut, yakni menghindari (menolak) masalah dan berkonfrontasi (menghadapi) masalah. Menghindari atau menolak masalah dengan cara mengelak. Berkonfrontasi 
atau menghadapi masalah dengan mengembangkan rencana atau upaya alternatif. Dengan demikian, penutur yang sedang menghadapi kendala ketika berkomunikasi dapat melakukan penghindaran atau menggunakan strategi komunikasi.

Selanjutnya, menurut Tarone (dalam Bialystok, 1990:37) bahwa tipologi strategi komunikasi terbagi menjadi wujud tipologi menghindar, wujud tipologi parafrase, wujud tipologi kesadaran transfer, dan wujud tipologi permintaan bantuan. Wujud tipologi menghindar mempunyai wujud strategi komunikasi menghindari topik/pindah ke topik lain dan ketinggalan pesan. Wujud tipologi parafrase mempunyai wujud strategi komunikasi, antara lain: perkiraan/penafsiran,

penciptaan/pembuatan kata-kata baru, dan pemakaian kata yang terlalu banyak/tidak perlu. Wujud tipologi kesadaran transfer mempunyai wujud strategi komunikasi, yaitu: penerjemahan literal dan alih bahasa. Wujud tipologi permintaan bantuan mempunyai wujud strategi komunikasi, yaitu: permintaan bantuan kepada penutur asli dan pada kamus. Wujud tipologi peniruan (termasuk komunikasi nonverbal) mempunyai wujud strategi komunikasi antara lain bertepuk tangan dan bahasa tubuh lainnya.

Tarone (dalam Bialystok, 1990:65) menyimpulkan beberapa kriteria yang mencirikan tahapan-tahapan seorang penutur menggunakan strategi komunikasi. Tahapan-tahapan tersebut, yaitu: (1) penutur ingin mengomunikasikan suatu makna (selanjutnya disebut makna X) kepada mitra tuturnya, (2) penutur yakin bahwa struktur linguistik dan struktur sosiolinguistik untuk mengomunikasikan makna X tidak tersedia atau tidak dapat tersampaikan kepada mitra tuturnya sehingga (3) penutur memilih: (a) menghindar, artinya tidak berusaha mengomunikasikan makna X tersebut kepada mitra tuturnya atau (b) berupaya memilih strategi alternatif dalam arti tetap mengomunikasikan makna $\mathrm{X}$ tersebut kepada mitra tuturnya. Penutur berhenti melakukan tahapan-tahapan tersebut apabila sudah tampak jelas bagi penutur bahwa telah terjadi penyampaian makna dalam komunikasi.

Beberapa faktor yang memengaruhi pemilihan strategi komunikasi oleh seorang penutur, antara lain: (1) level penguasaan bahasa penutur, (2) perolehan metode atau tugas khusus, misalnya apakah berupa deskripsi gambar, rekonstruksi gambar, penerjemahan, melengkapi kalimat, pertuturan/konversasi, narasi, instruksi, transmisi kata, atau wawancara, (3) pengaruh bahasa pertama, (4) berbicara dalam bahasa kedua (Bialystok, 1990:4854). Menurut Bialystok, penutur menggunakan tipologi strategi komunikasi tertentu karena beberapa sebab meliputi: (1) tingkatan pengetahuan dan kemampuan penutur, (2) bentuk pajanan tuturan yang diterima oleh penutur dari lawan tuturnya, (3) bahasa pertama (B1) yang telah diperoleh oleh penutur seringkali berpengaruh pada penguasaan bahasa kedua (B2) atau bilingual lainnya terutama yang sedang dipelajari oleh penutur, dan (4) setiap bahasa memiliki sistem kebahasaan sendiri.

\section{Pengaplikasian Komunikasi}

Strategi

Cara terbaik untuk menerangkan kegiatan komunikasi atau cara untuk menggambarkan dengan tepat sebuah tindak komunikasi ialah menjawab pertanyaan who says what in which channel to whom with what effect? siapa mengatakan apa dengan cara apa kepada siapa dengan efek bagaimana (Lasswell dalam http://kamuskomunikasi.blogspot.com, diakses pada 7 Desember 2016). Berdasarkan rumusan tersebut dapat ditelaah mengenai penutur yang harus 
mempunyai rasa percaya diri pada saat berkomunikasi. Strategi komunikasi harus dapat mencapai tujuan komunikasi yang diinginkan. Tujuan komunikasi yang diinginkan, yaitu: pesan atau informasi yang disampaikan oleh penutur dapat menimbulkan reaksi dari mitra tutur. Dengan efek tersebut, dapat ditetapkan bagaimana cara berkomunikasi dengan baik.

Implementasi strategi komunikasi harus luwes agar komunikator sebagai pelaksana dapat segera mengadakan perubahan apabila dalam pelaksanaan menemui hambatan. Salah satu cara untuk melancarkan komunikasi yang lebih baik mempergunakan pendekatan A-A Procedure (from Attention to Action Procedure) dengan lima langkah yang disingkat AIDDA. A adalah attention (perhatian); I adalah interest (minat); D adalah desire (hasrat); D adalah decision (keputusan); dan A adalah action (kegiatan).

Komunikasi dimulai dengan membangkitkan perhatian. Adanya perhatian akan menjadikan suksesnya komunikasi. Setelah perhatian muncul, diikuti dengan upaya menumbuhkan minat yang merupakan tingkatan lebih tinggi. Minat merupakan titik pangkal untuk menumbuhkan hasrat. Selanjutnya, seorang komunikator harus pandai membawa hasrat tersebut untuk menjadi suatu keputusan komunikan dalam melakukan suatu kegiatan yang diharapkan komunikator.

\section{METODE PENELITIAN}

Penelitian ini menggunakan jenis penelitian deskriptif kualitatif. Penelitian deskriptif kualitatif menghasilkan data deskriptif berupa kata-kata tertulis atau lisan dari orang-orang dan perilaku yang dapat diamati (Bogdan dan Taylor, 1975:5). Hal tersebut sesuai dengan penelitian ini karena penelitian ini menghasilkan data deskriptif kualitatif berupa tuturan guru dan siswa kelas XI SMAN 2 Sangatta Utara ketika menggunakan strategi komunikasi dalam proses pembelajaran bahasa Indonesia di kelas.

Data penelitian ini berupa perilaku dan tuturan guru dengan Siswa kelas XI SMAN 2 Sangatta Utara. Sumber data penelitian ini adalah guru dan siswa kelas XI SMAN 2 Sangatta Utara. Sumber data sebanyak satu orang guru dan siswa kelas XI SMAN 2 Sangatta Utara untuk mengumpulkan data.

Pengambilan data penelitian ini dilakukan pada bulan Maret-Oktober 2017. Pengambilan data dilakukan pada saat berlangsungnya KBM di kelas ketika guru sedang mengajar bahasa Indonesia. Dengan demikian, karakteristik pengambilan data dalam penelitian ini hanya mengambil data pada saat guru mengajar bahasa Indonesia dan pada saat guru lain mengajar, tidak diambil datanya.

Penelitian ini menggunakan teknik simak bebas libat cakap (SBLC) untuk merekam data tuturan dari subjek penelitian (Sudaryanto, 2015:204). Pengumpulan data menggunakan alat perekam audio visual dan lembar pengamatan yang akan digunakan untuk mencatat fenomena-fenomena yang muncul dalam komunikasi verbal dan nonverbal yang tengah berlangsung.

Setelah data diperoleh, semua data disajikan dalam bentuk teks tertulis, khususnya data yang berupa rekaman audio. Proses transkripsi data yang berupa rekaman audio akan dilakukan dengan dua cara. Pertama, proses transkripsi dilakukan secepatnya setelah data diperoleh. Langkah ini dilakukan dengan tujuan untuk mengurangi kesalahan menyimak rekaman dan menghindari kerusakan yang mungkin terjadi pada audio. Kedua, jika teknik pertama mengalami kendala, transkripsi data dilakukan setelah semua data terkumpul.

Penelitian ini menggunakan teknik analisis data, yaitu: (1) reduksi data, (2) penyajian data, dan (3) penarikan simpulan/verifikasi (Miles dan 
Huberman, 1992:16-19). Penelitian ini menggunakan analisis deskriptif untuk menganalisis data. Analisis deskriptif dilakukan dengan cara mengorganisasikan data, memilih data, dan pengodean (teknik koding). Selanjutnya dilakukan analisis dan interpretasi secara menyeluruh dengan mengarah ke fokus permasalahan yang dilakukan secara induktif. Agar penelitian kualitatif dapat memeroleh hasil analisis data yang valid, data yang telah diperoleh diperiksa dengan triangulasi.

\section{HASIL DAN PEMBAHASAN}

1. Strategi Komunikasi Antarteman ketika Proses Pembelajaran Bahasa Indonesia Siswa Kelas XI SMAN 2 Sangatta Utara

Berdasarkan hasil penelitian ini menunjukkan bahwa secara umum strategi komunikasi antarteman pada proses pembelajaran bahasa Indonesia oleh siswa kelas XI SMAN 2 Sangatta Utara terdiri atas 3 tipe, yaitu: (1) tipe parafrase, (2) tipe menghindar, dan (3) tipe peniruan. Ketika berkomunikasi, peserta tutur terutama penutur berusaha supaya maksud yang ingin disampaikan kepada mitra tuturnya dapat diterima. Oleh karena itu, penutur menggunakan beberapa strategi berkomunikasi. Ketika proses pembelajaran, siswa berkomunikasi dengan temannya. Misalnya, dengan teman sebangku, atau ketika berdiskusi dengan teman yang lain. Saat berkomunikasi itulah, mereka menggunakan berbagai strategi komunikasi.

\section{a. Tipe Peniruan}

Ketika berkomunikasi dengan teman di kelas, Ni'ma menggunakan strategi komunikasi peniruan. Strategi komunikasi peniruan yang digunakan oleh Ni'ma dan anggota kelompoknya, yaitu: menggunakan bahasa tubuh tertentu sesuai dengan makna komunikasi yang ingin dicapainya. Penggunaan bahasa tubuh tertentu oleh Ni'ma dapat dilihat pada kutipan berikut.

$\begin{array}{rlr}\text { (1) Aldi } & \text { saya Aldi sebagai } \\ & \text { pembunuh dan Raja. } \\ \text { Angel } & \text { : saya Angel sebagai Kurcaci } \\ & \text { pendiam dan narator. } \\ \text { Ni'ma } & \text { : Selamat menyaksikan! } \\ & \text { (diikuti anggota } \\ & \text { kelompoknyar sambil } \\ & \text { menundukkan badannya } \\ & \text { sebagai bentuk hormat } \\ & \text { kepada penonton) (1/LT- } \\ & \text { 047/TST) } \\ & \text { (pementasan pun dimulai) }\end{array}$

Strategi komunikasi peniruan yang digunakan oleh Ni'ma pada kutipan di atas, yaitu: menundukkan badannya sebagai bentuk rasa hormat kepada guru dan teman yang akan menyaksikan pementasan kelompoknya, Pada kutipan berikutnya Ni'ma juga menggunakan strategi peniruan pada saat berkomunikasi.

(2) Ratu : (berdiri dengan nada tinggi) kamu harus mencari yang namanya Snowait, Snowait, wait, wait itu! Pergi sudah, dia sudah mengalahkan kecantikanku, kamu tau?

Aldi : apa yang mulia?

Ni'ma : suut (sambil mengacungkan jarinya ke bibir si pembunuh seola menyuruh diam) (2/LT077/TST)

Aldi : di mana yang mulia?

Strategi komunikasi peniruan yang digunakan oleh Ni'ma pada kutipan di atas, yaitu: mengacungkan jarinya ke bibir sebagai bentuk instruksi untuk diam, dengan menggunakan strategi komunikasi dalam sebuah komunikasi, harapannya makna yang ingin disampaikan oleh Ni'ma dapat diterima dengan baik oleh mitra tuturnya.

\section{b. Tipe Kesadaran Transfer}


Ketika berkomunikasi dengan teman di kelas, Ni'ma menggunakan strategi komunikasi kesadaran transfer berupa pengalihan bahasa. Strategi komunikasi kesadaran transfer yang digunakan oleh Ni'ma dan anggota kelompoknya adalah pengalihan bahasa ke bahasa daerah, yaitu: weddus. Penggunaan pengalihan bahasa tertentu oleh Ni'ma dapat dilihat pada kutipan berikut.

(3) Susmita : kamu, bibibiii (bercanda disambut tawa siswa yang lain) ya akulah, dia itu salah, itu jantung rusa, pembunuh itu mengambil jantung rusa supaya Ratu tertipu (penonton pun tertipu)

Ni'ma : weddus orang itu (dengan nada kesal) (3/LT047/TAT)

Susmita : Jadi Ratu itu ditipu (mengulang lagi)

Ni'ma : ya sudah, sana kamu pergi (mengusir temannya dengan nada kesal)

Data di atas berupa strategi kesadaran transfer yang digunakan oleh Ni'ma, yaitu: pengalihan bahasa ke bahasa daerah, dengan menggunakan strategi komunikasi dalam sebuah komunikasi, harapannya makna yang ingin disampaikan oleh Ni'ma dapat diterima dengan baik oleh mitra tuturnya. Strategi Komunikasi antarteman yang peneliti temukan dalam penelitian ini, yaitu: strategi komunikasi tipe peniruan dan tipe kesadaran transfer, jenis strategi komunikasi yang lain tidak terjadi, menurut peneliti ada dua aspek yang menyebabkan hal tersebut, yaitu: (1) Ketika proses pembelajaran di kelas siswa lebih fokus pada pembelajaran yang disampaikan oleh guru (2) Interaksi di dalam kelas, ketika proses pembelajaran sedang berlangsung lebih banyak dikendalikan oleh guru yang berfungsi sebagai fasilitator dalam proses pembelajaran. Jadi, dapat disimpulkan bahwa ketika proses pembelajaran di kelas interaksi antara siswa dengan siswa relatif lebih sedikit dibanding interaksi antara siswa dengan guru, dan interaksi antara guru dengan siswa, hal tersebut bisa dibuktikan dari data strategi komunikasi yang terjadi pada saat proses pembelajaran, dari lima strategi komunikasi yang dikemukakan Tarone hanya dua strategi komunikasi yang digunakan oleh siswa ketika berinteraksi dengan temannya dalam proses pembelajaran.

\section{Strategi Komunikasi Siswa dan Guru ketika Proses Pembelajaran Bahasa Indonesia Kelas XI SMAN 2 Sangatta Utara}

Strategi komunikasi siswa dan guru SMA Negeri 2 Sangatta Utara umumnya menggunakan tipe parafrase dan tipe peniruan. Tipe parafrase mempunyai wujud strategi komunikasi, antara lain: (1) perkiraan/penafsiran, penciptaan/pembuatan kata-kata baru, dan (3) pemakaian kata yang terlalu banyak berupa penjelasan panjang lebar.

\section{a. Tipe Parafrase}

Idham dan Ni'ma pada saat berkomunikasi dengan guru di kelas, keduanya menggunakan strategi komunikasi parafrase. Strategi komunikasi parafrase yang digunakan oleh Idham dan Ni'ma, meliputi: perkiraan/penafsiran dan pemakaian kata yang terlalu banyak/tidak perlu. Idham dan Ni'ma juga menggunakan strategi komunikasi meminta bantuan kepada penutur asli. Dalam hal ini, penutur asli yang dimaksud adalah guru kelas.

\section{(1) Penafsiran}

Kutipan berikut ini menunjukkan penggunaan strategi komunikasi parafrase berupa penafsiran/perkiraan yang digunakan oleh Idham pada saat berkomunikasi dengan guru sebagai berikut. 
(4) Guru : sekarang, kalian menyimak ke layar yang di depan, kita akan belajar tentang resensi novel. (guru menjelaskan pengertian resensi) Mohon diperhatikan! Yang dimaksud dengan resensi berdasarkan etimologi, resensi berasal dari bahasa Laaa..... tin

Idham : Latin (diikuti siswa yang lain) (4/LT-025/TSG)

Guru : (melanjutkan penjelasan) dalam bahasa Belanda artinya pun sama (meyakinkan siswa) kemudian dalam bahasa Inggris disebut review, mengacu pada ulasan buku. Lanjut ini berdasarkan Kamus besar bahasa Indonesia, arti mengulas itu apa? (bertanya kepada siswa)

Pada kutipan di atas, Idham menafsirkan suku kata yang diucapkan oleh guru, yang pertama guru mengucapkan " $L$ a" kemudian diberi jeda, langsung dijawab oleh Idham "Latin" stimulus yang disampaikan oleh guru langsung dijawab atau dilanjutkan oleh Idham. Strategi komunikasi parafrase berupa perkiraan/penafsiran juga digunakan oleh Ni'ma dalam berkomunikasi dengan guru kelas. Kutipan berikut ini menunjukkan penggunaan strategi komunikasi parafrase berupa perkiraan/penafsiran yang digunakan oleh Ni'ma, sebagai berikut....

(5) Ni'ma : memberikan penjelasan

Guru : atau ko....

Ni'ma : Komentar 028/TSG)

Guru : lanjut .... kalau kita lihat di sini ulasan itu memiliki arti tersendiri yakni memberikan kupasan, ya... berarti kita mengomentari, berarti ulasan itu secara li...

Ni'ma : secara lisan (6/LT030/TSG)

Guru : berbeda dengan tulisan, kalau Anda diminta untuk memberikan komentar berdasarkan tulisan, berarti Anda menulis bukan mengomentari secara lisan.

Pada kutipan di atas, Ni'ma menafsirkan suku kata yang diucapkan oleh guru, yang pertama guru mengucapkan "Ko" kemudian diberi jeda, langsung dijawab oleh Ni'ma "Komentar," dan pada percakapan selanjutnya guru mengucapkan " $L \imath$ " kemudian diberi jeda, langsung dijawab oleh Ni'ma "Lisan." Stimulus yang disampaikan oleh guru langsung dijawab atau dilanjutkan oleh Ni'ma. Dengan demikian, penutur melakukan tipologi parafrase dengan tujuan utama untuk lebih meyakinkan dirinya bahwa mitra tuturnya dapat memahami pesan yang disampaikannya dengan baik.

\section{(2) Redudansi}

Strategi komunikasi parafrase digunakan oleh Guru dalam berkomunikasi dengan siswa di kelas. Parafrase yang digunakan oleh siswa berupa pemakaian kata yang terlalu banyak/tidak perlu dapat diketahui berdasarkan kutipan berikut.

(6) Siswa : siap.. siap (menyanggupi tawaran Bu Guru untuk tampil lebih maksimal) (siswa kembali mengatur tempat duduknya dengan rapi, dan kembali ke tempat duduknya seperti semula, kemudian mengakhiri pelajaran hari ini) $(7 /$ LT-216/TSG)

Guru : Nima. 
Nima : duduk siap grak, beri

Siswa : terima kasih, Bu.

Pada kutipan di atas, Siswa beberapa kali mengatakan 'siap'. Siswa menyebut kata 'siap' untuk lebih meyakinkan kepada guru bahwa mereka siap dan sanggup tampil maksimal pada pementasan berikutnya. Kemudian frasa "siap grak" yang disebutkan Ni'ma pada kutipan di atas tidak bermakna menyanggupi instruksi guru, tapi kata tersebut merupakan frasa instruksi untuk menyiapkan siswa dan sebagai penanda bahwa pelajaran akan berakhir.

\section{b. Tipe Permintaan Bantuan}

Strategi komunikasi meminta bantuan kepada guru kelas dapat dilihat pada kutipan berikut. Strategi komunikasi yang digunakan oleh Willy adalah strategi komunikasi meminta bantuan kepada penutur asli. Penutur asli yang dimaksudkan dalam penelitian ini adalah guru, karena guru diasumsikan sebagai orang yang berpengalaman dan berperan untuk memutuskan segalanya dalam kelas tersebut. Kutipan berikut menunjukkan penggunaan strategi komunikasi meminta bantuan kepada penutur asli.

\begin{tabular}{|c|c|}
\hline Guru & tanggalnya \\
\hline & $\begin{array}{l}\text { (Memerintahkan } \\
\text { seluruh siswa) }\end{array}$ \\
\hline Willy & $\begin{array}{l}\text { Dimana, Bu? } \\
\text { (Menanyakan dimana } \\
\text { menulis tanggal pada } \\
\text { lembar jawaban) (10/LT- } \\
\text { 088/TSG) }\end{array}$ \\
\hline
\end{tabular}

Kutipan di atas menunjukkan bahwa Willy bertanya kepada guru tempat untuk menulis tanggal pada lembar jawaban. Willy tidak bertanya ke teman lainnya di kelas tersebut karena Willy menganggap guru kelas adalah orang yang paling berpengalaman dan yang menentukan segalanya di kelas.

\section{c. Tipe Menghindar}

Pada kutipan percakapan antara siswa dan guru di bawah ini terjadi strategi komunikasi tipe menghindar berupa sikap diam ketika tidak mengetahui jawaban dari pertanyaan yang ditanyakan oleh guru.

(8) Guru : lanjut,.... ini adalah manfaat (menunjuk ke slide di depan) kalau ada tujuan berarti ada manfaatnya, apa manfaatnya?

Siswa : (diam, karena belum mengetahui apa manfaatnya) (11/LT053/TSG)

Guru : Saya berbicara ke resensi film, ketika kalian menonton film, film A dengan film B, itu kan kalian pasti membandingkan, terus kalian akan bilang film A tidak bagus film B yang bagus. Kalau saya tidak salah ingat, saya kemarin memberikan tayangan film tentang Batas, (mengingatkan pada materi pelajaran sebelumnya) ingat tidak? (12/LT-054/TSG)

Kutipan di atas menunjukkan terjadi strategi komunikasi tipe menghindar dari siswa berupa sikap diam ketika tidak mengetahui jawaban dari pertanyaan yang ditanyakan oleh guru, pada saat itu guru bertanya, "kalau ada tujuan berarti ada manfaatnya, apa manfaatnya?". Pada saat ditanya oleh guru semua siswa diam, karena belum mengetahui jawaban dari apa yang ditanyakan oleh guru, di lain sisi ada kemungkinan ragu untuk menjawab, atau siswa takut salah pada saat menjawab.

\section{d. Tipe Peniruan}


Ketika berkomunikasi dengan guru di kelas, Ni'ma menggunakan strategi komunikasi peniruan. Strategi komunikasi peniruan yang digunakan oleh Ni'ma, yaitu: menggunakan bahasa tubuh tertentu sesuai dengan makna komunikasi yang ingin dicapainya. Penggunaan bahasa tubuh tertentu oleh Ni'ma dapat dilihat pada kutipan berikut.

(9) Ari Eka : Kesimpulan.

Ni'ma : Itu untuk pembaca kah Bu? (bertanya kepada guru)

Guru : Iya..

Ni'ma : Cerita ini lain lagi?

Guru : Iya, cerita itu kan, berhubungan dengan kesimpulan kan?

Ni'ma : (menganggukkan kepalanya)

(13/LT-123/TSG)

Guru : Sudah ya? (bertanya kepada kelompok lain sambil bertepuk tangan) kelompok berapa ini?

Strategi komunikasi peniruan yang digunakan oleh Ni'ma pada kutipan di atas, yaitu: menganggukkan kepala untuk menunjukkan persetujuan atau mengiyakan pernyataan Guru dan temannya, dengan menggunakan strategi komunikasi dalam sebuah komunikasi, harapannya makna yang ingin disampaikan oleh Ni'ma dapat diterima dengan baik oleh mitra tuturnya.

Strategi Komunikasi antara siswa dan guru yang peneliti temukan dalam penelitian ini, yaitu: strategi komunikasi (1) tipe parafrase (penafsiran dan redudansi), (2) tipe permintaan bantuan, (3) tipe menghindar, dan (4) tipe peniruan, jenis strategi komunikasi tipe kesadaran transfer tidak terjadi, menurut peneliti ada dua aspek yang menyebabkan hal tersebut, yaitu: (1) Ketika proses pembelajaran di kelas siswa lebih fokus pada pembelajaran yang disampaikan oleh guru (2) Interaksi di dalam kelas, ketika proses pembelajaran sedang berlangsung lebih banyak dikendalikan oleh guru yang berfungsi sebagai fasilitator dalam proses pembelajaran. Jadi, dapat disimpulkan bahwa ketika proses pembelajaran di kelas interaksi antara siswa dan guru relatif berjalan baik karena dari lima strategi komunikasi yang kemukakan oleh Tarona sudah terjadi empat strategi komunikasi, hal tersebut terlihat dari data strategi komunikasi yang terjadi pada saat proses pembelajaran.

\section{Strategi Komunikasi Guru dan Siswa ketika Proses Pembelajaran Bahasa Indonesia Kelas XI SMAN 2 Sangatta Utara}

Strategi komunikasi guru dan siswa SMA Negeri 2 Sangatta Utara menggunakan lima tipe strategi komunikasi, akan tetapi dari kelima strategi komunikasi tersebut ada dua tipe strategi komunikasi yang dominan, yaitu: strategi komunikasi tipe parafrase dan tipe peniruan. Tipe parafrase mempunyai wujud strategi komunikasi, antara lain: (1) perkiraan/penafsiran, penciptaan/pembuatan kata-kata baru, dan (3) pemakaian kata yang terlalu banyak berupa penjelasan panjang lebar (eksposisi).

Tipe parafrase menjadi tipe yang paling banyak digunakan dalam proses pembelajaran khususnya berupa perkiraan/penafsiran dan penciptaan/pembuatan kata-kata baru. Hal ini menjadi sangat wajar karena peran guru sebagai pendidik profesional yang salah satu tugas utamanya adalah memfasilitasi siswa untuk memahami materi yang diajarkan. Selain itu, pada proses pembelajaran, guru berkomunikasi dengan siswanya untuk bertanya, menjelaskan sesuatu. Perbedaan usia di antara kedua partisipan tersebut juga mendorong tipe parafrase menjadi yang lebih dominan digunakan.

a. Tipe Parafrase 
Guru pada saat berkomunikasi dengan siswa di kelas, menggunakan strategi komunikasi tipe parafrase. Strategi komunikasi parafrase yang digunakan oleh guru, yaitu: pemakaian kata yang terlalu banyak berupa penjelasan panjang lebar (eksposisi). Strategi komunikasi parafrase digunakan oleh Guru dalam berkomunikasi dengan siswa di kelas adalah pemakaian kata secara panjang lebar, berupa uraian (paparan) yang bertujuan menjelaskan maksud dan tujuan. Hal tersebut dapat diketahui dari kutipan berikut.

(15) Guru : Informasi sekolahnya, sekaligus juga memberikan informasi tentang kampusnya melalui buku ini, dia akan mempromosikan buku ini, buku ini akan disebar luaskan iya, buku ini akan disebar luaskan dan dia akan mempromosikan tentang kampusnya, bercerita tentang alumnialumni, aktivitas mereka itu di dalam sini (mengacu pada buku yang dipegang), itu dikatakan sebagai sarana promosi. Oke, yang ketiga pengembangan kreativitas, dengan adanya resensi kan kita berarti apa? (18/LT-073/TGS)

Viola : Pelibatan.

Bayu : Sebagai bahan pelajaran.

Guru : Iya, dengan adanya resensi berarti kita semakin sering menulis, kalau salah perbaiki, iya inilah tujuannya sebagai pengembangan kreativitas, saya pernah minta kalian anak-anak tolong buat cerpen ya! Tolong buat novel! Kalian pasti berpikir kan? Setelah jadi satu kok penasaran, aku baca cerpennya temanku kok bagus ya Bu? Kalau begitu buat lagi, buat lagi, cerpen yang kalian sudah buat pasti ada dalam benak pikiran kalian itu, saya mau lanjutkan, ya, saya akan buat lagi $\mathrm{Bu}$, kayaknya eh kurang menarik ya yang pertama ya, saya mau lanjut lagi $\mathrm{Bu}$, boleh ya saya cerita tentang saya pribadi, silakan! Itu yang akan membuat kalian akhirnya menjadi penulis. Paham ya? (19/LT076/TGS)

Strategi komunikasi parafrase yang digunakan oleh Guru pada kutipan di atas, yaitu: pemakaian kata secara panjang lebar berupa teks eksposisi, yaitu: uraian (paparan) yang bertujuan menjelaskan maksud dan tujuan, hal itu dilakukan dengan tujuan utama untuk meyakinkan dirinya bahwa mitra tuturnya dapat memahami pesan yang disampaikannya dengan baik.

Berikut ini ada beberapa data strategi komunikasi parafrase dengan menggunakan teks eksposisi untuk menunjukkan bahwa strategi ini sering digunakan oleh Guru untuk menjelaskan materi pelajaran agar siswa dapat memahami atau menerima dengan baik materi pelajaran yang disampaikan oleh Guru kepada mitra tuturnya, yaitu: siswa.

(16) Guru : (melanjutkan Komentar, Nima sebagai Ratu dan nenek sihir, ketika Ratu dan Nenek Sihir, saya bingung (dengan ekspresi meyakinkan) ehb Ratu itu di awal ya? Ratu di awal, Ratu kok bawa tongkat (sambil menunjukkan gaya Nima sebagai Ratu 
membawa tongkat) ke mana-mana kok bawa tongkat, ketika dia menjadi nenek sihir tongkatnya dibawa lagi. Yaa, itu ya, koreksinya ya, trus ketika pertama kan, cermincermin (menirukan peran Nima sebagai Ratu) ini penontonnya di kasih cermin, cermin-cermin siapakah yang paling cantik? ee..harusnya Nima itu berdandan dulu (menirukan bagaimana harus berdandan di depan cermin) si cermin itu pun posisinya pun terlalu blocking (mengomentari si pemeran cermin) untuk Susmita itu seperti ini (diperagakan membelakangi penonton) jangan seperti ini! Buatlah agak condong (menirukan posisi menghadap penonton) yang Nima dia posisinya, perhatikan (sambil menirukan posisi yang tepat agar tidak blocking) Nima itu harus seperti ini (menirukan posisi yang tepat) jadi dia tidak blocking ke sana, harus seperti ini, setengah. Kalau tadi tidak seperti ini. Memang benar kalau kita bercermin kita berhadapan, tapi kalau kita sedang disaksikan orang, kita serong (merujuk pada etika pementasan di atas panggung) maka seperti ini, cermin-cermin (sambil menirukan cara berdandan dan bercermin) dia harusnya merapikan dulu, iya... ada gerak tubuh (sambil menirukan gerak tubuh) "cermin-cermin menurut kamu siapakah yang paling cantik di dunia? Siapa? Aku kan?" terus cerminnya "siapa lagi kalau bukan sang Ratu, Ratu kan yang paling cantik" (guru menirukan percakapan antara Ratu dan cermin dengan nada ekspresi dan gerak tubuh yang tepat) ada gerak seperti itu. Karena cermin tadi kan bisa berbicara, dia tidak boleh mem-blocking, gerak tubuhnya juga tidak perlu mutar-mutar, dia cukup sampai di sini bergerak (guru memberikan penjelasan meyakinkan sambil bertepuk satu kali untuk meyakinkan, siswa pun dengan serius menyimak). Kemudian ketika menyuruh, ee... memanggil pembunuh, peri sana! Itu kan harusnya ekspresinya marah. Karena dia ee.. merasa ada yang menyaingi kecantikannya, harusnya ketika dia menyuruh si Aldi tuk ee, ada kata geram ya, ada kata geram, karena di sini kan dialognya, kalau say perhatikan, lucunya itu ketemu memang, tapi marahnya kurang dipoles, na harusnya Aldi itu, siap "baik ratu" (menirukan suara maskulin seorang pembunuh) ada kewibawaan seorang... (20/LT-156/TGS)

Siswa : (serentak menjawab) Pembunuh...

Guru : (melanjutkan penjelasan) peran pembunuh, kenapa dikatakan wibawa, dia 
tidak boleh menunjukkan kekonyolan, atau kelucuannya itu, karena kalau dia pembunuh berarti kan wajahnya kan seram, orang yang disegani, galak gitu ya... Nima memerintahkan, "Aku tidak bisa terima, kamu harus cari Snowait, aku tidak bisa terima kalau Snowait paling cantik di dunia ini, sekarang, kamu cari sekarang!" (menirukan dialog yang harus dilakukan oleh Nima) ada perintah, menyuruh kepada pembunuh untuk mengambil si Snowait itu, membunuhnya. $\mathrm{Na}$, ee, apa, si Aldi mungkin harus menambah dialog " yang mana Snowait, di mana tinggal si Snowait" dia harus seperti itu. "pokoknya aku tidak mau tau, kamu harus cari dia, temukan dan bunuh dia!" (menirukan dialog Ratu yang sedang marah dan menyuruh si pembunuh). Siap, sambil jalan "siapa ya?" (menirukan apa yang harus dilakukan si pembunuh) jadi ada akting kebingungan. (21/LT158/TGS)

Strategi komunikasi parafrase yang digunakan oleh guru pada kutipan di atas adalah pemakaian kata secara panjang lebar berupa teks eksposisi yakni uraian (paparan) yang bertujuan menjelaskan maksud dan tujuan, hal itu dilakukan dengan tujuan utama untuk mengulas kembali penampilan kelompok yang baru saja melakukan pementasan secara bergantian. Dalam penjelasannya guru memberikan apa yang sebaiknya dilakukan dan yang seharusnya dihindari dalam sebuah pementasan, sehingga siswa yang tadinya kurang paham menjadi mengerti. Di bagian lain guru juga melakukan strategi parafrase berupa penjelasan panjang lebar, berikut kutipannya.

(17) Guru : Ah kan, emang suka marah, tapi mukanya belum dapat (mengoreksi ekspresi Eva) harus lebih maksimal, kemudian berbalik badan itu sudah bagus, ingat ya, "pokoknya kamu jangan kamu bukakan siapa pun, 'iya ya, bawel si"' (menirukan adegan yang diperankan Eva dan Alwi) na itu harusnya dari awal mengatakan seperti itu, boleh bawel, karena dia di kesal selalu diulang-ulang. Ok Eva dapat.

Kemudian ee... Atika, na ini benar, benar komentar kalian, ee... kurcaci bisu tapi reaksinya, bisunya kok masih ngomong, kemudian okelah, "ada apa si, ada apa si?" itu menunjukkan bahwa dia tidak mendengar, tapi reaksi yang lain dia tidak tau, tadi saya sempat melihat ada begini-begini (sambil menunjukkan tangannya berputar-putar di dekat telinga) ada yang seperti ini, Bayu ya? Bayu atau siapa ya, dia mengatakan bahwa dia bisu Bu, dia apa, dia tuli Bu, Aldi ya? Astrid ya? (Astrid pun mengangguk

membenarkan) $\mathrm{Na}$ itu bagus, "ada apa si, ada apa (22/LT-170/TGS) 


$\begin{array}{ll}\text { Atika } & \text { : Ada apa si, apaan? Siapa } \\ \text { ini? } & \text { : Ada apa si? Ah... ah... } \\ & \text { (memperagakan adegan } \\ & \text { tuli) harus seperti ini kan } \\ & \text { dia tidak mendengar, iya } \\ & \text { kan? Ada apa si, kamu cari } \\ & \text { siapa? Dia harus } \\ & \text { menunjukkan bahwa dia } \\ & \text { tidak dengar, ini reaksi dia } \\ & \text { tidak dengar itu ndak } \\ & \text { kedengaran, kurang ya? } \\ & \text { (23/LT-172/TGS) }\end{array}$

Strategi komunikasi parafrase yang digunakan oleh Guru pada kutipan di atas adalah pemakaian kata secara panjang lebar berupa teks eksposisi yakni uraian (paparan) yang bertujuan menjelaskan maksud dan tujuan, dalam penjelasannya guru memberikan apa yang sebaiknya dilakukan dan memberi contoh dialog dan ekspresi yang mestinya dilakukan oleh siswa pada saat melakukan pementasan, sehingga siswa yang tadinya kurang paham menjadi memahami.

\section{b. Tipe kesadaran transfer}

Strategi komunikasi kesadaran transfer guru dan siswa berupa pengajuan pertanyaan dan alih bahasa dapat dilihat pada kutipan berikut.

(18) Guru : Layak atau tidaknya untuk dibaca (mengulang jawaban Irza) yang lain! Ada yang lain? Favian? (24/LT-017/TGS)

Favian : Gak bisa $\mathrm{Bu}$, sama saja (maksudnya sama dengan jawaban temannya yang sudah menjawab)

Guru : Inilah yang dikatakan resensi berdasarkan etimologi, e yang pertama itu dari bahasa latin, dari kata kerja resentie atau resentere, yang berarti menilai, dalam bahasa
Belanda artinya sama, dalam bahasa Inggris disebut review, sama artinya mengulas, sementara dalam KBBI adalah pertimbangan atau pembicaraan tentang buku, mengulas buku, arti mengulas apa? Memberikan penjelasan dengan komentar. (25/LT-019/TGS)

Pada kutipan di atas, menunjukkan guru menggunakan strategi komunikasi kesadaran transfer ketika berkata "Ada yang lain? Favian?" dengan intonasi bertanya, hal ini sebagai wujud atau bagian dari strategi kesadaran transfer untuk memancing siswa menjawab apa yang dibahas dalam materi pembelajaran di kelas dalam hal ini mitra tutur guru adalah siswa yang bernama Favian, tapi faktanya Favian hanya memberikan persetujuan terhadap jawaban Irza, kemudian Guru melanjutkan penjelasan kembali terhadap materi pelajaran, yaitu: resensi, dalam penjelasan Guru juga menggunakan alih bahasa, yaitu: bahasa Yunani "resentie, resentere, dan review" ketika menjelaskan pengertian resensi, hal itu dilakukan oleh guru untuk meyakinkan siswa mengenai materi yang sedang dipelajari.

Strategi komunikasi kesadaran transfer guru dengan siswa berupa pengajuan pertanyaan dapat dilihat pada kutipan berikut.

(19) Guru : Ini tulisannya timbul, muncul dia, ini dikatakan dimensi, ini berhubungan dengan daya tarik, kemudian harga, $\mathrm{Bu}$ bukunya ini mahal ndak? Ndak bukunya murah hanya dijual sekitar Rp17500 padahal tebal ya, kalau murah kan biasanya, bagaimana kalau bukunya 
bermanfaat tipis ya? Pasti orang beli juga walaupun mahal. Kalian sama seperti menulis surat? Menulis surat tuannya untuk apa? Menyampaikan? (26/LT099/TGS)

Idham : Pesan.

Guru : Menyampaikan?

(27/LT-101/TGS)

Yoga : Keluhan.

Guru : Keluhan bisa jadi, ditujukan berarti kan ada orang yang dijadikan sasaran kan? (28/LT103/TGS)

Siswa : Iya.

Pada kutipan di atas, menunjukkan guru menggunakan strategi komunikasi kesadaran transfer ketika mengajukan kalimat tanya "Kalian sama seperti menulis surat? Menulis surat tuannya untuk apa? Menyampaikan?" dengan intonasi bertanya, hal ini sebagai wujud atau bagian dari strategi kesadaran transfer untuk memancing siswa menjawab apa yang dibahas dalam materi pembelajaran di kelas dalam hal ini mitra tutur guru adalah siswa yang bernama Idham dan Yoga serta siswa lain ada di kelas.

\section{c. Tipe Permintaan Bantuan}

Strategi komunikasi meminta bantuan kepada guru dapat dilihat pada kutipan berikut.

(20) Guru : Lanjut... jenis resensi itu ada tiga, yang pertama informatif, yang kedua deskriptif, dan kritis. Informatif berarti sudah jelas memberikan gambaran singkat, iya memberikan informasi berita, kemudian yang keempat eh yang kedua membahas secara detail setiap bab apa deskripsi?
Deskripsi itu sama dengan?

(29/LT-079/TGS)

Viola : Menggambarkan.

Guru : Menggambarkan dengan? (30/LT-081/TGS)

Ari Eka : Jelas.

Viola : Paparan.

Guru : Paparan itu apa ya? Ada yang tau apa itu paparan? (31/LT-084/TGS)

Viola : Menjelaskan.

Guru : Paparan itu mengulas, dia menjelaskan setiap bagian, jadi dijabarkan, kalau kita bilang diurai, diesaikan, ya diurai. Kemudian kritis, kritis sudah jelas menilai kan? Jadi, jenisnya ini kita meresensinya apakah hanya sebagai, oh ini resensinya tentang penjelasan saja, oh ini bukunya berisi tentang informasi saja atau justru ini buku tentang kritisan, mungkin suatu ketika di antara kalian mala membuat buku yang bercerita tentang kritis tentang bagaimana tindakan yang harus dilakukan pemerintah tentang bagaimana tindakan yang harus dilakukan pemerintah kita tentang jalur dari hadapan Telkom sampai ke simpang Munte karena sering banjir. Ada yang tinggal di daerah sana? (sambil mengangkat tangan kanannya) apa si penyebab banjir? Yang jelas pasti? (32/LT-086/TGS)

Pada kutipan di atas, menunjukkan guru menggunakan strategi komunikasi 
permintaan bantuan kepada siswa dengan mengajukan kalimat tanya untuk memancing siswa menjawab sekaligus memberi stimulus agar lebih interaktif dalam pembelajaran, "membahas secara detail setiap bab apa deskripsi? Deskripsi itu sama dengan?" kalimat tanya tersebut langsung dijawab oleh Viola "Menggambarkan" kemudian guru bertanya lagi "Menggambarkan dengan?" dijawab oleh Ari Eka "Jelas" kemudian Viola "Paparan" setelah itu Guru melanjutkan lagi bertanya "Paparan itu apa ya? Ada yang tau apa itu paparan?" kemudian dijawab lagi oleh Viola secara singkat "menjelaskan," dari dialog antara guru dan siswa terlihat bahwa Guru memberi stimulus kepada siswa berupa kalimat tanya agar siswa lebih aktif dan terlibat langsung dalam proses pembelajaran sehingga pembelajaran tidak hanya berfokus pada guru, tapi terjadi komunikasi dua arah.

\section{d. Tipe Menghindar}

Ketipan percakapan berikut adalah bentuk tipe menghindar.

(21) Guru : Kita diminta untuk mengkritik, memberikan saran isinya seperti apa, kemudian tulisannya, apakah kecil-kecil semua ataukah besar-besar ya... atau semuanya dicetak tebal-tebal. Kemudian ada kata substansi buku, ada yang paham apa itu subtansi buku? (bertanya kepada siswa) (33/LT048/TGS)

Siswa : (semua siswa diam)

Guru : (Guru menjawab sendiri pertanyaannya karena tidak dijawab oleh seluruh siswa dalam kelas) isinya, e... manfaat atau faedahnya dari si buku itu sendiri ada tidak, kalau tidak ada kita memberikan saran sebaiknya, hendaknya, seharunya boleh tidak? (bertanya kepada siswa). (34/LT-050/TGS)

Strategi komunikasi pada kutipan di atas, menunjukkan guru sedang menjelaskan materi pelajaran kepada siswa, setelah menjelaskan panjang lebar dan sampai pada kata "substansi buku" guru lalu mengajukan pertanyaan "ada yang paham apa itu substansi buku?" semua siswa diam karena tidak paham apa yang ditanyakan oleh guru, dari ilustrasi di atas terlihat bahwa siswa menggunakan strategi menghindar dengan cara diam karena tidak memahami apa yang ditanyakan oleh guru, dan siswa bersikap pasif serta tidak berusaha mencari solusi dari ketidaktahuannya terhadap materi, di sisi lain guru berinisiatif untuk menjelaskan kembali mengenai materi yang ditanyakan tersebut.

\section{e. Tipe Peniruan}

Kutipan berikut menunjukkan penggunaan strategi komunikasi peniruan berupa memindahkan bahasa oral menjadi bahasa tubuh untuk menunjukkan makna tertentu dalam komunikasinya, yang dilakukan oleh guru dengan siswa.

(22) Guru : (memantau keaktifan siswa sambil memberi penilaian di buku penilaian autentik atau penilaian secara langsung).

Memang benar ada beberapa penulisan yang kurang benar dalam penulisan cerpen (menguatkan presentasi perwakilan kelompok 1), kemudian presentasi kelompok dua! Sipa yang akan presentasikan? (beberapa siswa menyambut dengan tepuk 
tangan)

(35/LT-137/TGS)

Ari Eka : (berdiri mewakili

kelompok dua untuk presentasi) Assalamualaikum warahmatullabi wabarakatu

Siswa dan Guru:

Waalaikumsalamwarahmatull abi wabarakatu

Ari Eka : Saya dari kelompok dua ingin mempresentasikan resensi cerpen yang berjudul "Saya Sering Membuat Ibu Menangis"

Victor : (memotong) Pas.

Siswa : (Tertawa)

Guru : Ssttt (Menaruh 1 jari di mulutnya, memberi isyarat untuk diam) (36/LT143/TGS)

Strategi komunikasi peniruan yang digunakan oleh guru dengan siswa pada kutipan di atas, yaitu: bertepuk tangan dan menaruh satu jari di mulut. Siswa bertepuk tangan untuk memberikan semangat kepada kelompok 2 yang diwakili Ari Eka, yang akan mempresentasikan hasil diskusi kelompoknya, di bagian lain Guru mengacungkan jari telunjuknya di depan mulut sebagai penanda atau instruksi untuk menyuruh siswa diam dan mendengarkan apa yang dipresentasikan oleh kelompok 2 yang diwakili oleh Ari Eka. Dengan menggunakan strategi komunikasi dalam sebuah komunikasi, harapannya makna yang ingin disampaikan oleh Guru dan Siswa dapat diterima dengan baik oleh mitra tuturnya.

Strategi Komunikasi antara guru dan siswa yang peneliti temukan dalam penelitian ini, yaitu: strategi komunikasi (1) tipe parafrase, (2) tipe kesadaran transfer, (3) tipe permintaan bantuan, (4) tipe menghindar, dan (5) tipe peniruan. Jadi, dapat disimpulkan bahwa ketika proses pembelajaran di kelas interaksi antara guru dan siswa sudah berjalan baik karena dari lima strategi komunikasi yang kemukakan oleh Tarona kelimanya sudah dilakukan dalam proses pembelajaran di kelas. $\mathrm{Hal}$ tersebut terlihat dari data strategi komunikasi yang terjadi pada saat proses pembelajaran. Strategi komunikasi antara guru dan siswa terjadi dua arah, guru berfungsi sebagai fasilitator dalam proses pembelajaran. Guru memberi penjelasan panjang lebar berupa uraian, untuk memastikan materi yang disampaikan dipahami oleh siswa dengan baik. Strategi yang digunakan bisa lewat stimulus, berupa pengajuan pertanyaan, penerjemahan literal, dan ali bahasa. Pada saat guru memberi stimulus siswa juga berperan aktif, sehingga komunikasi dua arah itu terjadi.

Berdasarkan temuan data dalam penelitian ini, peneliti berkesimpulan bahwa proses pembelajaran, idealnya terjadi komunikasi banyak arah, yaitu: komunikasi yang melibatkan interaksi guru dengan siswa dan siswa dengan siswa yang lainnya. Proses pembelajaran yang menggunakan pola komunikasi semacam ini, akan membuat kegiatan siswa dalam kelas menjadi berkembang. Mereka dapat melakukan interaksi dengan sesama teman dan guru. Kegiatan siswa akan lebih optimal dengan interaksi semacam ini, tentu dengan peran seorang guru sebagai fasilitator dalam kelas sekaligus sebagai penggerak. Kebebasan dalam berekspresi membuat siswa menjadi lebih aktif. Melakukan diskusi dengan sesama teman membuat komunikasi siswa menjadi lebih berkembang, untuk mengatasi masalah komunikasi dalam proses pembelajaran, maka peran guru sebagai fasilitator dalam kelas yang berfungsi mengarahkan, memotivasi, dan memberi penjelasan. Sebuah pengaturan dalam proses belajar mengajar sangatlah dibutuhkan dari seorang guru berupa strategi dalam membangun komunikasi yang baik di dalam kelas pada saat proses pembelajaran.

\section{E. PENUTUP}


Berdasarkan hasil penelitian dan diskusi hasil penelitian, maka dapat ditarik beberapa simpulan. Berikut hal-hal yang dapat disimpulkan dari penelitian ini. Strategi komunikasi pada saat berkomunikasi, peserta tutur terutama penutur berusaha supaya maksud yang ingin disampaikan kepada mitra tuturnya dapat diterima dan dipahami dengan baik. Untuk itulah, penutur menggunakan beberapa strategi berkomunikasi. Ketika proses pembelajaran, siswa berkomunikasi dengan temannya. Misalnya, dengan teman sebangku, atau ketika berdiskusi dengan teman yang lain. Saat berkomunikasi itulah, mereka menggunakan berbagai strategi komunikasi.

Strategi Komunikasi antarteman yang peneliti temukan dalam penelitian ini, yaitu: strategi komunikasi tipe peniruan dan tipe kesadaran transfer. Strategi komunikasi peniruan yang digunakan oleh Ni'ma, yaitu: menggunakan bahasa tubuh tertentu sesuai dengan makna komunikasi yang ingin dicapainya. Ketika berkomunikasi dengan teman di kelas, Ni'ma juga menggunakan strategi komunikasi kesadaran transfer berupa pengalihan bahasa ke bahasa daerah, dengan menggunakan strategi komunikasi dalam sebuah komunikasi, harapannya makna yang ingin disampaikan oleh Ni'ma dapat diterima dengan baik oleh mitra tuturnya.

Strategi komunikasi di kelas kebanyakan dilakukan oleh guru pada saat berkomunikasi dengan siswanya. Ketika proses pembelajaran, guru berkomunikasi dengan siswanya untuk bertanya, menjelaskan sesuatu, dan lain sebagainya. Perbedaan usia di antara kedua partisipan tersebut memunculkan beberapa strategi. Saat berkomunikasi itulah, mereka menggunakan berbagai strategi komunikasi, di antaranya adalah strategi komunikasi tipe parafrase, tipe kesadaran transfer, tipe meminta bantuan, tipe menghindar, dan tipe peniruan.

\section{DAFTAR PUSTAKA}

Ahmadi, A. (2005). Psikologi Perkembangan. Jakarta: Rineka Cipta.

Aisyah. (2004). Strategi Komunikasi dalam Iklan Kampanye Partai Pemilu 2004 di Televisi. Tesis. Universitas Negeri Malang.

Arifin, T. (2000). Implikatur Percakapan Anak Usia Prasekolah. Tesis. Universitas Negeri Makassar.

Alwi, H. (1993). Tata Bahasa Baku Bahasa Indonesia. Edisi Ketiga. Jakarta: Departemen Pendidikan dan Kebudayaan.

Bialystok, E. (1990). Communication Strategies: A Psychological Analysis of Second-Language Use. Oxford: Basil Blackwell.

Blaiki, N. (2000). Designing Social Research: The Logic of Anticipation. Cambridge: Polity Press.

Bogdan, R. C. \& Taylor, S. I. (1975). Introduction to Qualitative Research to The Social Sciences. New York: John and Sons.

Brown, H. D. (2008). Prinsip Pembelajaran dan Pengajaran Bahasa. Jakarta: Kedubes AS.

Bulmer, M. (1982). The Use of Social Research. London: Allen and Unwin.

Chaer, A. (2009). Psikolinguistik: Kajian Teoritik. Jakarta: Rineka Cipta.

Clark, H. H. \& Clark, E. V. (1977). Psychology and Language: An Introduction to Psycholinguistics. San Diego: Harcourt Brace Jovanovich Publishers.

Corder, S. P. (1977). "Strategies of Communication" dalam Faerch, C. \& Kasper, G. (Eds). Strategies in Interlanguage Communication. Essex: Longman. 
Dardjowidjojo, S. (2002). Psikolinguistik: Pengantar Pemahaman Bahasa Manusia. Jakarta: Yayasan Obor Indonesia.

DeVito, J. A. (1997). Komunikasi Antarmanusia. Edisi ke-5. Jakarta: Professional Books.

Ellis, R. (1986). Understanding Second Language Acquisition. Oxford: Oxford University Press.

Ellis, R. (1989). Memahami Pemerolehan Bahasa Kedua. Malang: IKIP Malang.

Faerch, C. \& Kasper, G. (Eds.) (1983). Strategies in Interlanguage Communication. Essex: Longman.

Gunarsa, S. D. (2002). Psikologi Perkembangan Anak dan Remaja. Jakarta: PT BPK Gunung Mulia.

Haryono, A. (2006). Pola Komunikasi Antarkomunitas Pesantren Salaf "A" di Jember. Tesis. Universitas Negeri Surabaya.

Hasling, J. (1998). The Audience, The Message, The Speaker. Edisi VI. Boston: McGraw Hill.

Hastuti. (2003). Faktor-Faktor Penguasaan Babasa. Jakarta: PT Gramedia Pustaka Utama.

http://kamuskomunikasi.blogspot.com/ 2008, diakses pada 7 Desember 2016.

Kadir, A. (2010). Tuturan Taklangsung dalam Komunikasi Anak Usia Prasekolah di Play Group Melati Kids Purwosari Kabupaten Pasuruan. Tesis. Universitas Negeri Surabaya.

Kirk, S. A. \& Gallagher, J. J. (1989). Educating Exceptional Children. Edisi VI. Boston: Houghton Mifflin Company.

Kridalaksana, H. (1980). Fungsi Bahasa dan Sikap Bahasa. Ende Flores: Nusa Indah.
Kridalaksana, H. (2008). Kamus Linguistik. Edisi Keempat. Jakarta: PT Gramedia Pustaka Utama.

Larsen, F. \& Long, M. H. (1991). An Introduction to Second Language Aquisition Reseach. Longman: London and New York.

Liliweri, A. (2011). Komunikasi Serba Ada Serba Makna. Jakarta: Prenada Media Group.

Mar'at. (1997). Faktor-Faktor Perkembangan Kecerdasan Anak. Bandung: PT Remaja Rosdakarya.

Maria, M. (2009). Tuturan Penyandang Autis: Kajian Tindak Tutur, Prinsip Kooperatif, dan Strategi Komunikasi. Tesis. Universitas Negeri Surabaya.

Miles, M. B. \& Huberman, A. M. (1994). Qualitative Data Analysis (Inded). London: SAGE Publication.

Misnawati. 2009. Pandangan Hidup Masyarakat Dayak Ngaju dalam Karungut. Tesis. Universitas Negeri Surabaya.

Moleong, L. J. (2001). Metodologi Penelitian Kualitatif. Bandung: PT Remaja Rosdakarya.

Mulawarman, W. G., \& Iswanto, Y. (2018). Penerapan Teknik Bagi Unsur Langsung (BUL) pada Identifikasi Afiks Bahasa Dayak Benuaq. Diglosia: Jurnal Kajian Bahasa, Sastra, dan Pengajarannya, 1(1), 13-18. Diperoleh dari http:/ / diglosiaunmul.com/index.p $\mathrm{hp} /$ diglosia/article/view/5

Nababan, S. U. S. (1988). Psikolinguistik: Suatu Pengantar. Jakarta: Gramedia Pustaka Utama.

Nuryana, A. (2003). Pemerolehan Bahasa Kedua dengan Peranan Lingkungan. Tesis. Universitas Negeri Surabaya. 
Pateda, M. (1990). Aspek-Aspek Psikolinguistik. Ende-Flores: Nusa Indah.

Ramlan, M. (1983). Sintaksis. Yogyakarta: CV Karyono.

Rettob, T. (1992). Kajian tentang Strategi Komunikasi Pembelajar Bahasa Jerman (Sebuah Studi Kasus pada IKIP Surabaya). Tesis. IKIP Malang.

Rombepajung, J. P. (1988). Pengajaran dan Pembelajaran Babasa Asing. Jakarta: Depdikbud Dirjen Dikti.

Sudaryanto. (1993). Metode dan Aneka Teknik Analisis Babasa: Pengantar Penelitian Wahana Kebudayaan Secara Linguistik. Yogyakarta: Duta Wacana University Press.
Sugiono. (2009). Metode Penelitian Pendekatan Kuantitatif, Kualitatif dan R $\ll D$. Bandung: Alfa Beta.

Sumarsono \& Partana, P. (2004). Sosiolinguistik. Yogyakarta: Pustaka Pelajar

Sunarto. 2001. Metodologi Penelitian IlmuImu Sosial dan Pendidikan. Surabaya: Unesa University Press.

Supriyanto, T. (2009). Stilistika dalam Prosa. Jakarta: Pusat Bahasa.

Tarigan, H. G. (2009). Psikolinguistik. Bandung: Angkasa.

Yulianto, B. (2009). Perkembangan Fonologis Bahasa Anak. Surabaya: Unesa University Press. 